\title{
Evaluasi Penerimaan Mobile Aplikasi MandiriOnline Terhadap Minat Nasabah Menggunakan Metode UTAUT II (Studi Kasus: Bank Mandiri Cabang Solo)
}

\author{
Elvina Wahyuningsih ${ }^{1)}$, Bambang Soedijono W.A ${ }^{2)}$, Sudarmawan ${ }^{3)}$ \\ ${ }^{1}$ Program Pascasarjana Magister Teknik Informatika Universitas Amikom \\ YogyakartaJl. Ring Road Utara Condong Catur, Sleman, Yogyakarta, \\ Indonesia \\ Email : ${ }^{1}$ elvina.wahyuningsih@amikom.ac.id
}

\begin{abstract}
Abstrak
Fenomena layanan digital yang terjadi di Indonesia saat ini sangat menarik. Mobile Banking merupakan layanan digital di bidang perbankan. Layanan dilakukan dengan tujuan untuk mempermudah nasabah melakukan transaksi keuangan (perbankan) untuk penggunaan teknologi informasi (Mobile Banking). Mobile Banking diartikan sebagai fasilitas bagi nasabah bank untuk dapat melakukan aktifitas perbankan mereka secara lebih leluasa, dimana saja, kapan saja, dan tanpa harus secara fisik mengunjungi bank tersebut. Layanan yang disediakan menyesuaikan mobilitas konsumen. Guna memenuhi harapan konsumen, perbankan melakukan inovasi dengan mengikuti perkembangan teknologi informasi dan memberikan kemudahan kepada konsumen dalam melakukan transaksi, diantaranya dengan fitur ATM, SMS banking, internet banking, phone banking dan mobile banking. Evaluasi sistem informasi merupakan aspek penting dalam menilai keberhasilan implementasi sistem informasi. Tujuan utama evaluasi penerimaan Aplikasi Mobile Mandiri Online terhadap minat Nasabah menggunakan metode UTAUT II yaitu untuk menguji adanya pengaruh performance expectancy, effort expectancy, social influence, facilitating condition, hedonic motivation, price value, dan habit terhadap minat nasabah menggunaan mobile banking pada nasabah Mandiri cabang Solo.
\end{abstract}

Kata kunci: Mobile Banking, Mandiri Online, Aplikasi, Bank MANDIRI, UTAUT I

\section{PENDAhuluan}

Fenomena layanan digital yang terjadi di Indonesia saat ini sangat menarik. Mobile Banking merupakan layanan digital di bidang perbankan. Nasabah sudah merasakan kenyamanan dengan layanan yang ada, layanan perbankan yang dikenal denganistilah Mobile Banking memberikan nasabah informasi dan membntu menyelesaikan berbagai urusan perbankan secara cepat, mudah dan tanpa batas tempat dan waktu (Sulistriyani, 2013). Kemajuan teknologi informasi yang pesat dapat mempengaruhi industri perbankan, perusahaan harus memiliki keunggulan kompetitif antara lain dengan mengadopsi fasilitas teknologi informasi dan memberikan layanan kepada konsumen.

Layanan dilakukan dengan tujuan untuk mempermudah nasabah melakukan transaksi keuangan (perbankan) untuk penggunaan teknologi informasi (Mobile Banking).

Layanan yang baik akan membentuk sikap positif nasabah terhadap perusahaan dan niat untuk tetap menggunakan jasa layanan jasa perbankan yang bersangkutan. Mobile Banking secara umum adalah saluran distribusi Bank untuk mengakses rekening yang dimiliki nasabah melalui teknologi penyampaian data melalui ponsel atau general package radio service (gprs) dengan sarana telepon seluler (ponsel). Penggunaan teknologi informasi dan komunikasi di dunia perbankan relative lebih maju dibandingkan sektor lainnya. Berbagai jenis teknologi diantaranya Anjungan Tunai Mandiri atau dalam bahasa Inggris Automated Teller Machine (ATM), Banking Application System, Real Time Gross Settlement System, Sistem Kliring Elektronik dan Internet Banking. Mobile Banking merupakan layanan perbankan yang berfungsi untuk memudahkan nasabah dalam melakukan transaksi perbankan tanpa perlu datang ke bank atau ATM kecuali penarikan uang cash. Keunggulan Mobile Banking yaitu nasabah 
dapat melakukan transaksi dimana saja dan kapan saja tanpa dibatasi waktu. Layanan pada Mobile Banking meliputi: transaksi finansial, transaksi non finansial, transfer dana, cek saldo dan pembayarantagihan yang dilakukan lewat telepon seluler. Mandiri online merupakan aplikasi internet banking dan mobile banking untuk nasabah Bank Mandiri (Wibowo, et al, 2020).Mandiri online adalah layanan e-banking untuk melakukan transaksi finansial dan non finansial dengan menggunakan menu transaksi dan tampilan menu, dimana aplikasi harus diunduh terlebih dahulu menggunakan handset telepon selular/ tablet serta teknologi 3G/GPRS/WIFI. Keuntungan menggunakan mandiri online memudahkan nasabah untuk melakukan transaksi,dapat digunakan dimana saja dan kapan saja, transaksi dan proses pendaftaran mudah serta aman (Tavisar el, al 2015).

Kebanyakan dari nasabah bank menginginkan suatu pelayanan yang sederhana dan praktis. Pelayanan manual ini dirasa kurang efisien, karena secara riil kesibukan orang sebagai nasabah pada saat ini semakin meningkat. (Machmud et al. 2010). Mandiri Mobile Banking adalah layanan Mobile Banking pada Smartphone (Blackberry, Android, dan iPhone) dengan tampilan menu yang menarik dan mudah digunakan. Mandiri Mobile dapat melakukan transaksi finansial (transfer, pembayaran, pembelian, dll), transaksi non finansial (cek saldo, cek histori transaksi, dll), informasi lokasi cabang/ATM, informasi kurs dan fiturfitur menarik lainnya).

Terdapat model untuk mengukur dan mengevaluasi penggunaan teknologi, salah satunya yang akan digunakan dalam penelitian ini adalah model UTAUT 2 (Unified Theory of Acceptance and Use of Technology 2). UTAUT 2 merupakan pengembangan model UTAUT yang sebelumnya, dimana UTAUT2 mempelajari penerimaan dan penggunaan dari sebuah teknologi yang lebih berpusat pada konteks konsumen (Venkatesh et al, 2012). Tujuan dari model UTAUT 2 adalah mengidentifikasi tiga variabel penting dari penelitian penerimaan dan penggunaan teknologi baik untuk umum maupun konsumen, memodifikasi beberapa hubungan yang sudah ada pada konsep model UTAUT terdahulu, dan mengenalkan hubungan baru (Venkatesh et al, 2012). Tiga variabel baru yang ditambahkan ialah Hedonic Motivation (HE), Price Value (PV), dan Habit (H).

Sebelumnya beberapa peneliti telah menggunakan model tersebut pada penelitian evaluasi. Diantaranya ialah Alotaibi dan Wald (2014) yang menerapkan model UTAUT untuk mengevaluasi pengalaman penerimaan pengguna pada Identity Access Management Systems (IAMS) yang menghasilkan bahwa terdapat ketidakberpengaruhan pada perilaku penggunaan, kemudian Frank dan Markovic (2018) yang menerapkan UTAUT2 untuk mengvaluasi e-Government Project dimana menghasilkan semua hipotesis memiliki pengaruh yang signifikan, lalu Kalamatiandan Malamateniou (2017) yang menerapkan UTAUT2 dengan tujuan mendeskripsikan sebuah model evaluasi untuk menginvestigasi kesuksesan e- Government Project dimana hasilnya variabel gender, social influence, dan hedonic motivation secara tidak signifikan memiliki pengaruh. Maka dari beberapa penelitian tersebut, mempertegas bahwa model UTAUT2 telah digunakan untuk penelitian terkait evaluasi.

Penelitian ini akan memfokuskan pada pemanfaatan UTAUT II sebagai kerangka teoritis untuk mengetahui pengaruh faktor atau konstruksi UTAUT II terhadap penerimaan Mobile aplikasi Mandiri Online khususnya Mandiri kantor cabang Solo.

\section{METODE PENELITIAN}

Beberapa tahapan dalam penelitian dapat dilihat pada Gambar 1 di bawah ini.

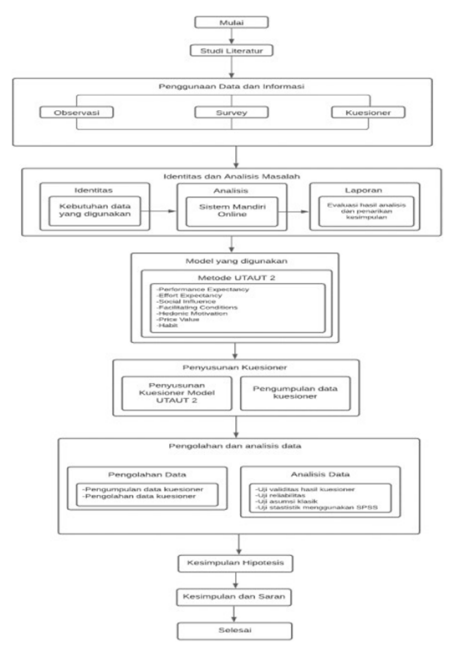

Gambar 1. Alur Penelitian

Gambar di atas merupakan langkah-langkah tahapan alur penelitian yang akan digunakan 
dalam penelitian ini meliputi:

\section{a. Studi Literatur}

Mengetahui berbagai penelitian terdahulu yang mempunyai kaitan dengan penelitian yang dilakukan. Identifikasi masalah, merumuskan latar belakang masalah, rumusan masalah, batasan masalah, tujan penelitian, dan manfaat penelitian.

b. Pengumpulan Data dan Informasi Penyusunan menggunakan model

UTAUT 2 yang terdiri dari. Survey berupa pengisian kuesioner dan wawancara secara langsung dengan nasabah Bank Mandiri Cabang Solo yang menggunakan Mandiri Online

\section{c. Identifikasi dan Analisis Data}

Setelah data terkumpul dilakukan uji validitas dan reabilitas untuk mengetahui tingkat keandalan dan kesahihan alat ukur yang digunakan. Menunjukkan sejauh mana pengukuran dapat memberikan hasil relatif pada kuesioner dan wawancara.

\section{d. Pengolahan dan Analisis Data}

Uji statistik menggunakan software SPSS, asumsi berupa uji normalitas, uji multikolinearitas dan uji heteroskedasitas serta menggunakan software SmartPLS untuk menguji hubungan antara variabel, baik sesama variabel latent maupun dengan variabel indikator, atau manifest.

\section{e. Pengujian Hipotesis}

Melakukan pengujian instrument hipotesis dengan pengolahan data SPSS dan menyimpulkan hasil pengujian terhadap analisis data yang telah dilakukan.

\section{f. Kesimpulan dan Saran}

Kesimpulan dan saran yang didapatkan dari penelitian yang telah dilakukan. Penyusunan laporan merupakan tahapan terakhir untuk hasil dari keseluruhan penelitian.

\section{TINJAUAN PUSTAKA}

Ada beberapa penelitian yang pernah dilakukan salah satunya oleh Penelitian Venkatesh et al., (2012). Melalui Unified Theory of Acceptance and Use of Technology
(UTAUT 2) dapat diketahui bagaimana penerimaan dan penggunaan dari sudut pandang peserta didik sebagai konsumen pengguna teknologi e-learning. Model UTAUT 2 merupakan sebuah model yang dikembangkan untuk secara efektif memprediksi, menjelaskan dan menganalisis perilaku penerimaan teknologi masyarakat untuk produk teknologi informasi. Terkait dengan penggunaan UTAUT 2 untuk mengetahui penerimaan dan penggunaan elearning, peneliti tidak memasukkan konstruk Price value ke dalam model yang akan diteliti dengan asumsi bahwa subjek penelitian telah memiliki media elektronik sehingga tidak memerlukan biaya untuk membeli perangkat elektronik tambahan, oleh sebab itu peneliti hanya menggunakan delapan variabel.

Serta ada juga Huda dan Fertina (2018) terhadap 127 pengguna e-money Bank Mandiri yang berada di Kecamatan Ciputat. Hasil penenlitian menunjukkan bahwa dari 10 hipotesis yang diuji, mayoritas hipotesis diterima sebanyak 7 hipotesis dan yang ditolak sebanyak 3 hipotesis. Variabel habit merupakan faktor dengan perngaruh terbesar dan effort expectancy menjadi faktor dengan pengaruh terkecil. Manfaat dari penelitian yang diberikannya dapat menjadi rekomendasi terkait dengan model UTAUT2 yang dapat dijadikan sebagai bahan pertimbangan untuk pengembangan e-money Bank Mandiri kedepannya.

\section{HASIL DAN PEMBAHASAN a. Gambaran Umum Objek Penelitian}

Penelitian ini bertujuan untuk menguji adanya pengaruh performance expectancy, effort expextancy, socialinfluence, facilitating condition, hedonic motivation, price value, dan habit terhadap minat nasabah menggunaan mobile mandiri online pada nasabah Mandiri cabang Solo.

Jenis penelitian ini adalah penelitian kuantitatif dengan menguji hipotesis. Metode pengumpulan data menggunakan metode survey dengan kuesioner dalampengumpulan data. Objek dalam penelitian ini adalah seluruh nasabah pada Bank Mandiri cabang Solo. Populasi dalam penelitian ini adalah seluruh nasabah yang menggunakan Bank Mandiri mobile banking di Solo. Sampel dalam penelitian ini adalah nasabah yang menggunakan layanan mobile banking pada 
Bank Mandiri di Solo. Teknik pengambilan sampel dalam penelitian ini menggunakan metode accidental sampling.

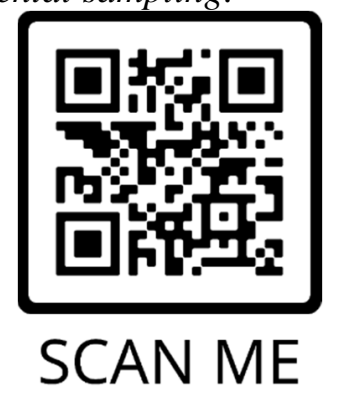

Gambar 2. QR Code Link Kuesioner

Banyak kuesioner yang disebar berdasarkan kesedian nasabah yang menggunakan layanan mobile banking pada Bank Mandiri cabang Solo menjadi responden dalam penelitian ini. Pelaksanaan penelitian ini dengan membagikan kuesioner secara langsung kepada responden dengan alternatif scan QR Code yang mengarah ke link kuisioner.

Metode pengambilan sampel dengan metode convinience sampling yaitu teknik pengambilan sampel secara bebas. Jumlah kuesioner yang diperoleh dan dapat diolah sebanyak 268 kuesioner. Proses pengambilan sampel berdasarkan responden pada Bank Mandiri cabang Solo ditunjukkan pada ditunjukkan pada tabel 1 dibawah ini :

Tabel 1. Jumlah Kuisioner

\begin{tabular}{|l|l|}
\hline Kriteria & Jumlah \\
\hline Kuesioner yang disebar & 268 \\
\hline Kuesioner yang kembali & 268 \\
\hline $\begin{array}{l}\text { Respon rate }=268 / 268 \\
\text { x100\% }\end{array}$ & $100 \%$ \\
\hline Data yang diperoleh & 268 \\
\hline $\begin{array}{l}\text { Data yang tidak dapat } \\
\text { diolah }\end{array}$ & 0 \\
\hline Jumlah Kuesioner Siap & 268 \\
\hline Dianalisis & \\
\hline $\begin{array}{l}\text { Usable respon rate }=268 \\
\text { /268 x }\end{array}$ & $100 \%$ \\
\hline $100 \%$ & \\
\hline
\end{tabular}

Dari data yang diperoleh dengan menggunakan kuesioner yang diberikan secara langsung kepada responden. Berdasarkan tabel 1 diketahui bahwa kuesioner yang disebar peneliti sebanyak 268 kuesioner kepada responden, kuesioner yang kembali sebanyak 268 kuesioner. Total sampel yang digunakan dalam penelitian ini sebanyak 268 kuesioner.

\section{a. Uji Validitas}

Uji validitas digunakan untuk melihat sejauh mana suatu alat pengukur itu bisa mengukur apa yang ingin diukur. Guna melihat valid atau tidaknya sebuah data maka kolom yang dilihat adalah kolom pearson correlation. Dikatakan valid jika rhitung > 0,1697 . Untuk melihat tingkat validitas semua item pernyataan kuesioner yang penulis susun, dapat dilihat pada tabel 2. di bawah ini.

Tabel 2. Hasil Uji Validitas Variabel

\begin{tabular}{|l|l|l|l|l|}
\hline No & Indikator & $\begin{array}{c}\mathbf{r} \\
\text { hitung }\end{array}$ & $\begin{array}{c}\text { simpula } \\
\mathbf{n}\end{array}$ & Keterangan \\
\hline 1 & PE_1 & 0,853 & Valid & $\begin{array}{c}\text { r hitung > } \\
0,1697\end{array}$ \\
\hline 2 & PE_2 & 0,875 & Valid & $\begin{array}{c}\text { r hitung > } \\
0,1697\end{array}$ \\
\hline 3 & PE_3 & 0,874 & Valid & $\begin{array}{l}\text { r hitung > } \\
0,1697\end{array}$ \\
\hline
\end{tabular}

\section{c. Persamaan Regresi Linier Berganda}

Hasil perhitungan dan pengolahan data dengan menggunakan Statistical Program for Social Science (SPSS), didapatkan tabel coefficients dibawah ini. Dari tabel 4. dapat diambil beberapa kesimpulan, salah satunya adalah persamaan regresi linier berganda.

Tabel 3. Hasil Uji Regregi Berganda Coefficients $^{\mathrm{a}}$

\begin{tabular}{|c|c|c|c|c|c|}
\hline $\begin{array}{l}\text { Unstandard } \\
\text { ed } \\
\text { Coefficient }\end{array}$ & & & $\begin{array}{l}\text { Standardi } \\
\text { zed } \\
\text { Coefficie } \\
\text { nts }\end{array}$ & $\mathrm{t}$ & Sig. \\
\hline Model & B & $\begin{array}{l}\text { Std. } \\
\text { Error }\end{array}$ & Beta & & \\
\hline 1(Constant & 3.416 & 1.091 & & 3.132 & .002 \\
\hline PE & .1 .746 & .0134 & .1486 & $\begin{array}{l}26.20 \\
8\end{array}$ & .000 \\
\hline $\mathrm{EE}$ & -.0 .476 & .0194 & -.278 & -4.906 & .030 \\
\hline SI & .0 .050 & .0102 & .056 & .972 & .1256 \\
\hline HM & .0 .456 & .0174 & .258 & .4 .886 & .010 \\
\hline PV & 0.030 & .082 & .036 & .952 & 1236 \\
\hline
\end{tabular}

Melihat nilai Unstandardizet Coefficients Beta di atas, maka dapat ditentukan 
persamaan regresi linier berganda yang dihasilkan daripenelitian ini, sebagai berikut: $\mathrm{Y}=3,416+1,746 \mathrm{X}_{1}-0,476 \mathrm{X}_{2}+0,050 \mathrm{X}_{3}$ $0,456 \mathrm{X}_{4}+$ $0,030 \mathrm{X}_{5}$

Yang berarti bahwa:

a Konstanta sebesar 3,416 yang berarti jika variabel Performance expectancy, Effort expextancy, Social influence, Hedonic Motivation dan Price Value dianggap nol maka variabel Behavior intention hanya sebesar 3,416.

b. Koefisien regresi variabel Performance expectancy diperoleh nilai sebesar 1,746 yang berarti jika variabel Performance expectancy mengalami kenaikan sementara variabel Effort expextancy, Social influence, Hedonic Motivation dan Price Value diasumsikan tetap maka variabel Behavior intention juga akan mengalami kenaikan sebesar 1,746.

c. Koefisien regresi variabel Effort expextancy diperoleh nilai sebesar 0,476 yang berarti jika variabel Effort expextancy mengalami kenaikan sementara variabel Performance expectancy, Social influence, Hedonic Motivation dan Price Value diasumsikan tetap maka variabel Behavior intention akan mengalami penurunan sebesar 0,476.

d. Koefisien regresi variabel Social influence diperoleh nilai sebesar 0,050 yang berarti jika variabel Social influence mengalami kenaikan sementara variabel Performance expectancy, Effort expextancy,Hedonic Motivation dan Price Value diasumsikan tetap maka variabel Behavior intention juga akan mengalami kenaikan sebesar 0,050.

e. Koefisien regresi variabel Hedonic Motivation diperoleh nilai sebesar 0,456 yang berarti jika variabel Hedonic Motivation mengalami kenaikan sementara variabel Performance expectancy, Effort expextancy, Social influence dan Price Value diasumsikan tetap maka variabel Behavior intention akan mengalami kenaikan sebesar 0,456.

f. Koefisien regresi variabel Price Value diperoleh nilai sebesar 0,030 yang berarti jika variabel Price Value mengalami kenaikan sementara variabel Performance expectancy, Effort expextancy, Social influence dan Hedonic Motivation diasumsikan tetap maka variabel Behavior intention akan mengalami kenaikan sebesar0,030.

\section{d. Uji SmartPLS}

Pengujian ini dilakukan untuk menjelaskan varian dari tiap target endogenous variabel (variabel yang dianggap dipengaruhi oleh variabel lain dalam model) dengan standar pengukuran sekitar 0,670 sebagai kuat, sekitar 0,333 moderat, dan 0,190 atau di bawahnya menunjukan tingkat varian yang. Untuk mendapat nilai R2 dapat dihitung melalui:

Tabel 4. Hasil Uji R-square denganSmartPLS

\begin{tabular}{|l|c|}
\hline \multicolumn{1}{|c|}{ Variabel } & $\begin{array}{c}\mathbf{R} \\
\text { Square }\end{array}$ \\
\hline Behavioral Intention & 0.862 \\
\hline Use Behavior & 0.855 \\
\hline
\end{tabular}

1) T-test

Pada tahap pengujian t-test ini dilakukan melalui metode bootstrapping pada SmartPLS, menggunakan uji two - tailed dengan tingkat signifikansi $10 \%$ untuk menguji hipotesis - hipotesis penelitian. Hipotesis tersebut akan diterima jika memiliki t-test lebih besar dari 1,645. Untuk meperoleh nilai t-test dapat dihitung melalui rumus berikut:

Tabel 5. Hasil Uji T-test Dilihat dari hasil pengujian $t$-test

\begin{tabular}{|l|l|}
\hline $\begin{array}{l}\text { Hubungan antar } \\
\text { Variabel (Jalur) }\end{array}$ & \multicolumn{1}{|c|}{ T-test } \\
\hline $\mathrm{PE} \rightarrow \mathrm{BI}$ & 26.208 \\
\hline $\mathrm{EE} \rightarrow \mathrm{BI}$ & -4.906 \\
\hline $\mathrm{SI} \rightarrow \mathrm{BI}$ & 972 \\
\hline $\mathrm{FC} \rightarrow \mathrm{BI}$ & 17.110 \\
\hline
\end{tabular}




\begin{tabular}{|l|l|}
\hline $\mathrm{HM} \rightarrow \mathrm{BI}$ & -4.886 \\
\hline $\mathrm{PV} \rightarrow \mathrm{BI}$ & 1.952 \\
\hline $\mathrm{HT} \rightarrow \mathrm{BI}$ & 17.090 \\
\hline $\mathrm{FC} \rightarrow \mathrm{UB}$ & 17.110 \\
\hline $\mathrm{HT} \rightarrow \mathrm{UB}$ & 17.090 \\
\hline $\mathrm{BI} \rightarrow \mathrm{UB}$ & 7.208 \\
\hline
\end{tabular}

pada tabel 4.36 bahwa terdapat tiga nilai t-test yang kurang dari 1,654 yaitu adalah hubungan antara variabel EE?BI yang memiliki nilai ttest -4.906 , SI?BI yang memiliki nilai t- test 972, dan HM?BI yang memiliki nilai t-test 4.886. Dengan kata lain hasil ini menunjukkan bahwa dari 10 hipotesis terdapat tiga hipotesis yang tidak diterima.

\section{e. Pengujian Hipotesis}

Pengujian hipotesis dilakukan dengan melihat besarnya nilai pada tabel dari tabel coefficient pada tabel 4.35. dan tabel 4.36. Nilai tabel digunakan sebagai batas untuk menolak atau menerima hipotesis. Apabila $t_{\text {hitung }}$ berada pada renta nilai $t_{\text {tabel, }}$ maka hipotesis ditolak dan dengan kata lain menerima $\mathrm{H}_{0}$.

\begin{tabular}{|c|c|c|}
\hline Inisial & Hipotesis & Hasil \\
\hline $\mathrm{H} 1$ & Harapan & Diterima \\
\hline $\mathrm{H} 2$ & $\begin{array}{l}\text { Harapan akan } \\
\text { usaha (Effort } \\
\text { expextancy) } \\
\text { mempunyai } \\
\text { Pengaruh } \\
\text { positif terhadap } \\
\text { minat untuk } \\
\text { berperilaku } \\
\text { (Behavior } \\
\text { intention) }\end{array}$ & Ditolak \\
\hline H3 & $\begin{array}{l}\text { Pengaruh sosial } \\
\text { (Social } \\
\text { influence) } \\
\text { mempunyai } \\
\text { pengaruhPositif }\end{array}$ & Ditolak \\
\hline
\end{tabular}

\begin{tabular}{|c|c|c|}
\hline & $\begin{array}{l}\text { terhadap minat } \\
\text { untuk } \\
\text { berperilaku } \\
\text { (Behavior } \\
\text { intention) }\end{array}$ & \\
\hline $\mathrm{H} 4$ & $\begin{array}{l}\text { Kondisi } \\
\text { pendukung } \\
\text { (Facilitating } \\
\text { condition) } \\
\text { mempunyai } \\
\text { pengaruh positif } \\
\text { terhadap } \\
\text { perilaku } \\
\text { pengguna (Use } \\
\text { behavior) }\end{array}$ & Diterima \\
\hline H5 & $\begin{array}{l}\text { Motivasi } \\
\text { Hedonis } \\
\text { (Hedonic } \\
\text { Motivation) } \\
\text { mempunyai } \\
\text { pengaruh } \\
\text { positif terhadap } \\
\text { minat untuk } \\
\text { berperilaku } \\
\text { (Behavior } \\
\text { intention) }\end{array}$ & Ditolak \\
\hline H6 & $\begin{array}{l}\text { Nilai Harga } \\
\text { (Price Value) } \\
\text { mempunyai } \\
\text { pengaruh } \\
\text { positifterhadap } \\
\text { minat untuk } \\
\text { berperilaku } \\
\text { (Behavior } \\
\text { intention) }\end{array}$ & Diterima \\
\hline $\mathrm{H} 7$ & $\begin{array}{l}\text { Kebiasaan } \\
\text { (Habit) } \\
\text { mempunyai } \\
\text { pengaruh } \\
\text { positif terhadap } \\
\text { perilaku } \\
\text { pengguna (Use } \\
\text { behavior) }\end{array}$ & Diterima \\
\hline H8 & $\begin{array}{l}\text { Minat untuk } \\
\text { berperilaku } \\
\text { (Behavior } \\
\text { intention) } \\
\text { mempunyai } \\
\text { pengaruh positif } \\
\text { terhadap }\end{array}$ & Diterima \\
\hline
\end{tabular}




\begin{tabular}{|l|l|l|}
\hline & $\begin{array}{l}\text { perilaku } \\
\text { pengguna (Use } \\
\text { behavior) }\end{array}$ & \\
\hline
\end{tabular}

\section{KESIMPULAN DAN SARAN \\ a. Kesimpulan}

Berdasarkan hasil pembahasan dan analisis yang telah dilakukan, dapat diambil kesimpulan bahwa:

1. Secara keseluruhan hasilperformance expectancy, price value, habit dan faciliting conditions Mandiri Mobile Banking mempunyai hasil positif (diterima) serta mempengaruhi behavior intention nasabah, tetapi disisi lain berbanding terbalik dengan effort expectancy, social influence, hedonic motivation yang mendapakan respon negative (ditolak) dari sisi behavior intentionnasabah.

2. Hasil facilitating condition, Habit dan behavior intention terhadap use behavior Mandiri online secara bersama-sama sudah cukup mempengaruhi sebesar 40,9\% nasabah cabang Solo sedangkan sisanya sebesar $49,1 \%$ dipengaruhi oleh variabel lainnya yang tidak termasuk dalam penelitian ini.

3. Rekomendasi yang dihasilkan menunjukan bahwa Mandiri online sudah sesuai dengan kebutuhan nasabah, hanya saja dari segi tampilan aplikasi berdasarkan dari effort expectancy masih ada yang kebingungan dengan tampilan pada User Interface mobile banking Mandiri masih belum user friendly.

4. Berdasarkan metode UTAUT2, Performance expectancy mempengaruhi aplikasi Mandiri online secara dominan pada penelitian di Bank Mandiri cabang Solo.

\section{b. Saran}

Berdasarkan penelitian yang telah dilakukan, maka saran yang dapat diberikan penulis untuk penelitian selanjutnya sebagai berikut :

1) Pada penelitian yang telah dilakukan terdapat dua uji yang digunakan sebaiknya penelitian selanjutnya menggunakan uji lainnya untuk memperkuat atau mendapatkan hasilyang lebih akurat dan optimal.

2) Pada penelitian selanjutnya seharusnya dilakukan di Bank Mandiri Cabang yang berbeda.

\section{REFERENSI}

Jogiyanto, H. M. (2007). Sistem informasi keperilakuan. Yogyakarta: Andi Offset. Sugiyono, Prof., Dr. (2012). Metode Penelitian Kuantitatif Kualitatif dan R\&D. Alfabeta, CV, Bandung

Wirawan. (2012). Evaluasi: Teori, Model, Stadar, Aplikasi dan Profesi, Rajawati Pers, Jakarta

Nematollahi, M., Moosavi, A., Lazem, M., Aslani, N., Kafashi, M., \& Garavand, A. (2017). Factors affecting in adoption and use of electronic medical record based on unified theory of acceptance and use of technology in Iran. Shiraz EMedical Journal, 18(9).

Pavlou, P. A. (2003). Consumer Acceptance Of Electronic Commerce: Integrating Trust And Risk With The Technology AcceptanceModel. International Journal Of Electronic Commerce, 7(3), 101134.

Prabo, A. S. (2015). Evaluasi Penerimaan User Teknologi Mobile Banking di Yogyakarta (Doctoral dissertation, Universitas Gadjah Mada) 